\title{
APPLICATION OF A HOLISTIC APPROACH OF HYDROGEN INTERNAL COMBUSTION ENGINE (HICE) BUSSES
}

\author{
Salehi, Vahid Douzloo \\ Munich University of Applied Sciences
}

\begin{abstract}
Hydrogen is a promising fuel to fulfil climate goals and future legislation requirements due to its carbon-free property. Especially hydrogen fueled buses and heavy-duty vehicles (HDVs) strongly move into the foreground. In contrast to the hydrogen-based fuel cell technology, which is already in commercial use, vehicles with hydrogen internal combustion engines (H2-ICE) are also a currently pursued field of research, representing a potentially holistic carbon-free drive train. Real applications of H2-ICE vehicles are currently not known but can be expected, since their suitability is put to test in a few insolated projects at this time. This paper provides a literature survey to reflect the current state of H2-ICEs focused on city buses. An extended view to HDVs and fuel cell technology allows to recognize trends in hydrogen transport sector, to identify further research potential and to derive useful conclusion. In addition, within this paper we apply green MAGIC as a holistic approach and discuss Well-to-Tank green hydrogen supply in relation to a H2-ICE city bus. Building on that, we introduce the upcoming Hydrogen-bus project, where tests of H2-ICE buses in real driving mode are foreseen to investigate Tank-to-Wheel.
\end{abstract}

Keywords: Sustainability, Circular economy, Product Lifecycle Management (PLM)

\section{Contact:}

Salehi, Vahid

Munich University of Applied Sciences

Mechatronics

Germany

salehi-d@hm.edu

Cite this article: Salehi, V. D. (2021) 'Application of a Holistic Approach of Hydrogen Internal Combustion Engine (HICE) Busses', in Proceedings of the International Conference on Engineering Design (ICED21), Gothenburg, Sweden, 16-20 August 2021. DOI:10.1017/pds.2021.48 


\section{INTRODUCTION}

\subsection{Literature survey and background of this paper}

This section reveals the requirement of decarbonization, seen as a key driver of hydrogen technology. In this context we would like to discuss two aspects.

The first aspect relates to the relevance of road freight transport towards carbon-free technologies. Driven by a global increasing demand for all fuels, global energy-related carbon dioxide (CO2) emissions rose $1.7 \%$ in 2018 to a historic high of 33.1 Gt CO2 (IEA, 2019). The transport sector as one of the largest contributor accounts around $22 \%$ of the global energy-related CO2-emissions (2015). Within this sector, road freight transport is responsible for approximately $40 \%$ and will continue to increase (OECD/IEA, 2017). In the EU, on road CO2-emissions are predicted with $45 \%$ to come from HDVs in 2030 (Delago and Muncrief, 2016). It should be mentioned that CO2 is seen as the major greenhouse gas (GHG) and receives most attention (Kluschke et al., 2019). In consequence of increasing emission rates, the climate change scenario, which has been described as the biggest challenge of the 21 st century, calls for action. In short: A rapid and significant reduction of GHG-emissions is elementary required, in order to contain existing risks and keep impacts on natural and human systems as low as possible (Pachauri and Mayer, 2015). Especially since the stock of heavy-duty vehicles (HDV) is almost $100 \%$ based on diesel fuel at present, road freight activities play a major role regarding CO2-emissions within transport sector. In Addition, the technical possible $\mathrm{CO} 2$ reduction potential of current diesel technologies lies less than $15 \%$ (Kluschke et al., 2019). Summarized there is an urgent need to push carbon-low or carbon-zero drive trains for mobility applications (Lozanovski et al., 2018).

The second important aspect we would like to address are the political measures towards decarbonization. Policy responses of many countries worldwide can already be identified by setting both transnational and individual targets. The UN Conference of Parties (COP21) Paris agreement in 2015 provided the regulatory frame for a global movement away from fossil fuels towards low-carbon technologies, where 195 UNFCCC participation member states agreed to achieve long-term GHG emission reductions (United Nations, 2015). As a result, various Public Private Partnerships were founded to bring forward mobile hydrogen applications. With respect to the implementation of hydrogen fueled busses in Europe, exemplary projects are CHIC (2010-2016) and JIVE (ongoing) (Hydrogen Europe, 2020). In addition, a recently announced 'H2Bus' consortium should be mentioned aiming to deploy $1.000 \mathrm{FC}$ electric buses within the EU in total and 600 vehicles due by 2023 (H2Bus, 2020). Another response of COP 21 seen as a key driver in the realisation of sustainable mobile applications are increasingly strict upcoming cross-country policies. For example, the amended Clean Vehicle Directive (CVD) 2009/33/EG in the EU, which promotes sustainable road transport vehicles, by setting fixed procurement rates for clean and emission-free vehicles (European Union, 2009). Last but not least according to the literature reviewed the majority agree, that without further political measures the development of $\mathrm{H} 2$ will be hampered and emissions will continue to rise (Ambel, 2017).

\subsection{Hydrogen combustion technology versus counterparts}

Hydrogen (H2) as a fuel is not new, but the development for use in a commercial transport system is accelerating up to date. Hence, in the following section we clarify the status quo of H2-ICE technology for buses in the foreground as well as HDVs and the much better known and much more frequently used fuel cell technology (FC) representing the hydrogen-based counterpart.

More and more vehicle manufacturers see high potential in $\mathrm{H} 2$ fuel for mobile applications, reflected in an increasing foundation of joint ventures and cooperations between OEMs and other associated companies. For instance, the Volvo Group formed a joint venture with Daimler Truck AG to develop and commercialize FC systems for HDVs and other applications (Eliasson and Martens, 2020). Another example represents the Korean car manufacturer Hyundai, who recently brought in cooperation with $\mathrm{H} 2$ Energy the first fuel cell electric series truck on Swiss market into operation: The Hyundai Xcient FC model (Hyundai, 2020). On the other hand, the EU-funded project 'H2Haul' aims to develop and deploy long-haul heavy duty FC trucks at four European countries (H2Haul, 2020). Summed up, several H2 projects and applications exist, which differ in their level of maturity from pilots to commercial use. It should be mentioned that all currently used $\mathrm{H} 2$ vehicles are based on fuel cells, showing that this is the dominant technology in the hydrogen mobility sector. 
On the contrary, by now, a small number of manufacturers attempt to use hydrogen in internal combustion engines, called H2-ICE. This means to use hydrogen similar to conventional fuels like gasoline or diesel in combustion engines, with the main difference, that due to it's carbon-free content the hydrogen combustion process emits no $\mathrm{CO} 2$ emissions. NOx pollutants are the only exhaust gases that can occur, but according to Korn and Volpert (2019) their concentration goes towards zero. Further substantial arguments in favor of the H2-ICE technology are the use of existing manufacturing structures, a high tolerance to hydrogen purities and a much more better cost situation compared to fuel cells (Eichlseder et al., 2020). Real H2-ICE applications in daily operation are not known, neither from HDVs nor from city buses. Studies or research results of H2-ICE - especially in terms of real data - are thus limited but efforts are on the upswing, represented by only few insolated but noteworthy projects:

- MAN, a HDV-OEM hast just published their electric and hydrogen roadmap announcing that they are testing both fuel cells and internal combustion engines (VW AG, 2020)

- MAN Truck \& Bus, University Nuremberg-Erlangen (FAU) and University of Technology Nuremberg (THN) have concluded a R\&D cooperation agreement for hydrogen fuel cells and combustion engines in trucks and buses (FAU, 2020)

- Within the Hydrogen-bus project, an upcoming project that will be introduced here, the intention is to test $\mathrm{H} 2$-ICE buses in real driving mode

As already stated, with H2-ICE and FC there are two types of hydrogen-based drive trains which should not be confused, therefore, their operating principles will be introduced briefly. Both technologies have in common to run on hydrogen as well as their package in terms of on-board storage and supply is largely the same. The fundamental difference in between is the principle applied, as shown in Figure 1.
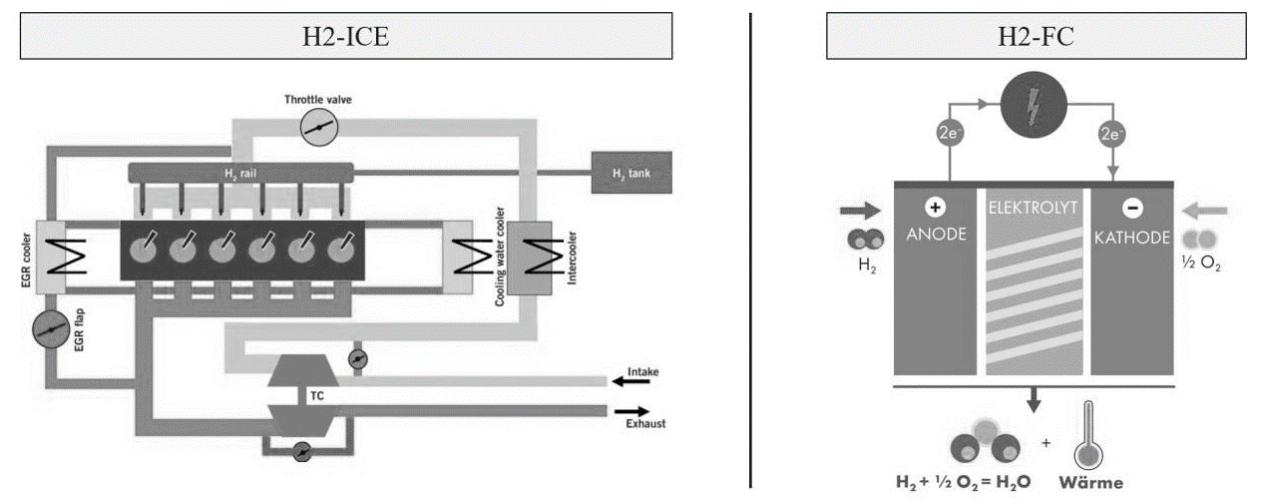

Figure 1. Comparison of H2-ICE (Koch et al., 2020) and H2-FC (Adolf et al., 2017)

H2-ICE vehicles are based on a conventional ICE as known from diesel or gasoline vehicles, means four stroke cycle including $1^{\text {st }}$ intake, $2^{\text {nd }}$ compression, $3^{\text {rd }}$ power and $4^{\text {th }}$ exhaust. The result generated by the hydrogen combustion process is mechanical work (Klell et al., 2018). Which engine concept the most suitable for combustion to hydrogen constitutes, is currently being researched in various ways. At the University of Technology Graz, a 2.0 series gasoline engine was modified for operation with hydrogen and is tested with both external (PFI) as well as internal mixture formation with direct injection (DI) (Eichlseder et al., 2020). Klepatz et al. (2019) compared efficiencies of H2- DI and H2MPI engines with a reference diesel engine and reveals risks and advantages of the investigation. The authors pointed out that the injection has a huge significance of H2-ICE performances. A similar result emerges from Yip et al. (2019) who compared different H2 injection and ignition methods and concluded that H2-DI achieves high engine efficiencies combined with low emissions. Finally, Korn and Volpert (2019) introduced a hybrid model by combination of two simple and well-known systems, a H2-ICE and a $48 \mathrm{~V}$ electric motor. With this new hybrid drive train, they eliminated the disadvantages of each technology and created a propulsion system that seems to be suitable for heavyduty urban vehicles. Besides the use of pure hydrogen in ICEs, hydrogen blended fuels were also proven for reducing CO2-emissions. For instance, El Hannach et al. (2019) analysed a diesel-H2 mix, while Gupta et al. (2020) assessed a CNG-H2 blend. These applications are more seen as short-term or temporary solution supporting up to a consistent hydrogen economy, as the advantage of $\mathrm{CO} 2$-free combustion is no longer given due to mixing. A fuel cell on the contrary is a device that converts chemical bounded energy of the fuel $(\mathrm{H} 2)$ with the use of oxygen gas $(\mathrm{O} 2)$ directly into electrical energy. The generated electricity is essentially provided to power vehicle electric motors, to charge the 
energy storage system and to support auxiliary loads. The only products beside electricity are water and heat. For road transport applications including HDVs and buses, the FC type PEMFC (Proton exchange membrane) is the consensus choice and the most common one (Reich and Reppich, 2018). While comparing efficiency between H2-ICE and FCtechnology we can assert significant benefit in favor of the latter. According to Wietschel et al. (2016) currently used FC achieve efficiency between $45 \%$ and $59 \%$. These efficiency benefits of FC have been confirmed by Reuter et al. (2017) in context of buses, resulting in obvious lower $\mathrm{H} 2$ fuel consumptions. Figure 2 presents an overview with respect to $\mathrm{WtT}, \mathrm{TtW}$ and $\mathrm{WtW}$ efficiencies of $\mathrm{H} 2-\mathrm{ICE}, \mathrm{FC}$ and diesel technology. The real impact of the reduced H2-ICE efficiency on $\mathrm{H} 2$ fuel consumption would have to be investigated in practical driving conditions, as for H2-ICE buses or HDVs meaningful data aren't existent at this time. On the other hand, the widespread market penetration of fuel cell technology is being inhibited particularly because of their above-average costs, mostly assessed as TCOs (Gnann et al., 2017) whereas H2-ICEs achieve advantages (Eichlseder et al., 2020).

\begin{tabular}{|c|c|c|c|}
\hline & $\eta$-WTT (Fuel) & $\eta$-TTW (Vehicle) & $=\quad \eta$-WTW (Mobility) \\
\hline $\mathrm{H} 2+\mathrm{ICE}$ & $\sum 43-58 \%^{1}$ & $40 \%{ }^{2}$ & $>17-23 \%$ \\
\hline H2 + FCEV & $\sum 43-58 \%^{1}$ & $\sum 45-59 \%^{3}$ & $>19-34 \%$ \\
\hline Diesel ICE & $\begin{aligned} & 84 \%^{1} \\
& \text { Cnde oil based }\end{aligned}$ & $>19-22 \%^{1}$ & \begin{tabular}{|l}
$>16-18 \%$ \\
\end{tabular} \\
\hline
\end{tabular}

Figure 2. Efficiency chain of H2-ICE, FC and diesel ICE technologies (European Union, 2014) ${ }^{1}$; (Koch et al., 2020 $)^{2}$; (Wietschel et al., 2016)

Besides hydrogen fuel, intensive research has also been done on several other 'carbon-reduced' or 'carbon-free' forms of propulsion, summarized as alternative fuels and powertrains (AFP). As this paper is less a benchmark, we just mention most important AFP which can be subdivided according to Kluschke et al. (2019) as follows:

- alternative fuels include six different types of fuel (LPG, LNG, CNG, eMET, eSYN, BIO)

- $\quad$ powertrain contains four electrified powertrains (CAT, BEV, HYB + FC)

\subsection{Contribution of this work}

In this paper we would like to address the quality and quantity of H2-ICE technology applied in city buses by means of a holistic method. In addition, we are going to implement the impacts of green hydrogen. For this reason, we chose green MAGIC approach by Salehi (2020) as the overall framework. An extended view to trucks and fuel cells allows us to recognize trends in $\mathrm{H} 2$ transport sector, to identify further research potential and to derive advantageous conclusion for Hydrogen-bus project.

\subsection{Application of green MAGIC approach}

Applied green MAGIC as seen in Figure 3 represents an adopted approach of the Munich Agile MBSE Concept (MAGIC) of Salehi and Wang (2019). Green MAGIC integrate the holistic Well-to-Wheel chain where we identify six fundamental steps comprising 1) Source of Hydrogen, 2) Energy Production, 3) Conversion, 4) Storage \& Transport, 5) Fueling \& Application and 6) Further Usage.

The reason for the application of Munich Agile Concept is the holistic consideration of the so called Well-To-Wheel (WTW) and Tank-To-Wheel (TTW) in an Closed Loop cycle Approach. Furthermore, the by means of the green MAGIC Approaches it is possible to use this kind of sustainability aspects in a systematic and formalized way to define the requirements, functions, architecture and the validation phase of such end-to-end assessment of sustainability. Furthermore, the research question was if it is possible to adopt approaches from Munich Agile Concept to go through the entire process of WTW and TTW consideration. The following paper wanted also to carry out result if Systems Engineering Approaches could help to get a better understanding of such sustainability aspect like WTW and TTW which are implemented in other domains. 


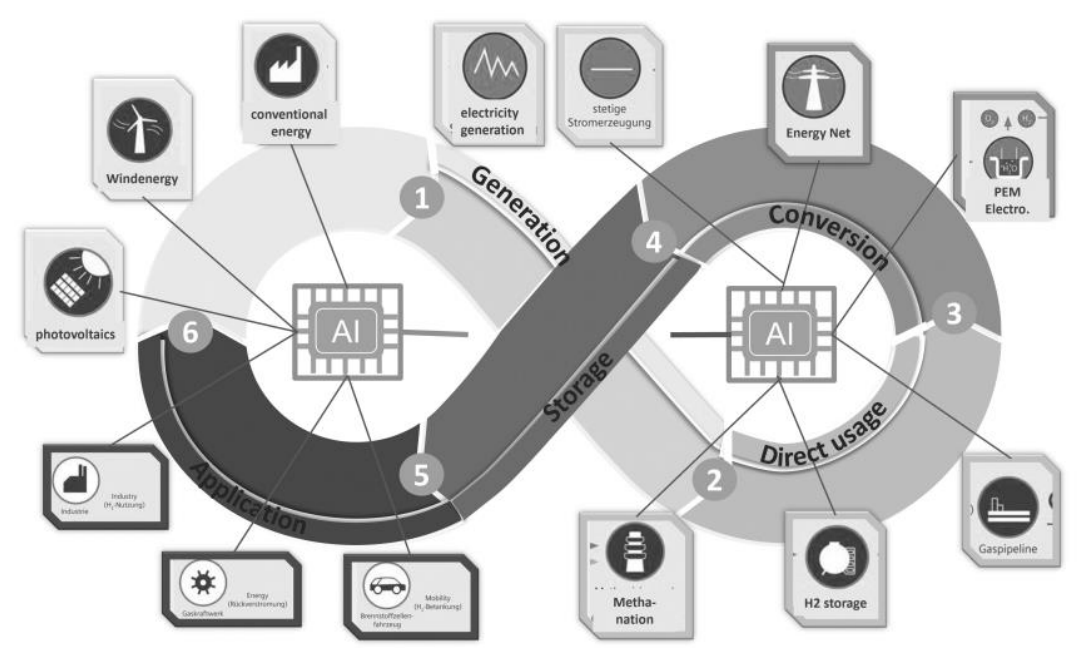

Figure 3. Green MAGIC approach (Salehi, 2020)

Common methodologies applied to this kind of analyse are usually known as Well-to-Wheel (WtW) approaches, but many of them lack the infinity idea. Especially when dealing with hydrogen, which is more an energy carrier than only a fuel, precisely these implemented feedback loops are declared necessary. Within green MAGIC the two WtW pillars are identified as:

- Well-to-Tank (WtT), represented by green MAGIC step 1 to 4, comprising all the processes from primary sources transfered to the ready-to-use fuel

- Tank-to-Wheel (TtW), represented by green MAGIC step $5+6$, essentially related to vehicle operation (Guandalini and Campanari, 2018)

In addition to WtW using for ecological analysis, Life Cycle Assessment (LCA) or 'cradle-to-grave' are also frequently chosen methods. Life-cycle assessment or LCA (also known as life-cycle analysis) is a methodology for assessing environmental impacts associated with all the stages of the life-cycle of a commercial product, process, or service. For instance, in the case of a manufactured product, environmental impacts are assessed from raw material extraction and processing (cradle), through the product's manufacture, distribution and use, to the recycling or final disposal of the materials composing it (grave). In general, there are controversial discussions about the clear definition of $\mathrm{WtW}$ and LCA, which are particularly about the limits of consideration, called 'system boundaries'.

\section{GREEN MAGIC APPLIED ON A H2-ICE CITY BUS}

This section introduces green MAGIC step 1 to 4 from Well to Tank. We go into each step, describe the most important issues and point out which influences arise on a H2-ICE city bus. The pending Tank-toWheel investigation, represented by green MAGIC step 5 and 6 , will be object of the upcoming Hydrogen-bus project, where we intend to involve real, practical data. It should be mentioned that the combination of individual steps below is complex and lead to a variety of possible pathways. We concentrate exclusively on our focus. The same applies to all the papers reviewed, considering certain paths, which differ in their quantity and depth and have been selected based on their respective objects of investigation.

\subsection{Step 1: Source of Hydrogen}

Since $\mathrm{H} 2$ does not occur naturally in its pure form, it must be produced using energy. Various processes are applied for this purpose, using different primary energy carriers and hydrogen compounds, which can be evaluated by eighter efficiency or $\mathrm{CO} 2$ emissions. The first options covering about $95 \%$ of worldwide's $\mathrm{H} 2$ production are large-scaling conventional procedures based on fossil hydrocarbons. Thereof, steam methane reforming (SMR) represents the most common and most economical one. Other noteworthy conventional methods are auto-thermal reforming, partial oxidation and coal gasification. They all have in common to achieve high efficiency (70-80\%), but on the other hand they are increasingly critical due to large amounts of $\mathrm{CO} 2$ associated. A second option represents electrolysis of water by means of electricity, which currently covers about $5 \%$ of worldwide's $\mathrm{H} 2$ production. In terms of $\mathrm{CO} 2$ emissions, the source of electricity is the elementary factor. Since water electrolysis based on renewable energies is considered as the potentially only commercial method to produce 'green' 
hydrogen, we will discuss this path further in green MAGIC step 2 and 3. Both conventional processes and electrolysis are specially developed for the $\mathrm{H} 2$ production and make up a share of together $60 \%$ of $\mathrm{H} 2$ usage. The other $40 \%$ of used $\mathrm{H} 2$ emerges as a by-product of industrial processes, mostly from chlorine-alkali electrolysis, representing the third $\mathrm{H} 2$ source. In terms of $\mathrm{CO} 2$ pollution, the decisive factor of by-product $\mathrm{H} 2$ is how the emissions generated are distributed proportionally among the end products, which may cause the values to differ. As a fourth option we define carbon-reduced strategies based on fossil sources, known as CCS: 'carbon capture and sequestration' (Klell et al., 2018). According to Töpler and Lehmann (2017) there are possible CO2 separation rates between 50 up to 90 $\%$, while costs behave analogously. As fifth option we mention direct thermal cracking of fossil hydrocarbons which can produce $\mathrm{H} 2$ without $\mathrm{CO} 2$, but due to high temperatures needed the energy input is large and the $\mathrm{H} 2$ yield relatively low. Most recently there are options like biomass gasification, biological procedures using algae and photochemical procedures, for instance, which are still in conception stage and thus no longer considered. Beside all $\mathrm{H} 2$ sources discussed above, there is also to clarify, weather if $\mathrm{H} 2$ is produced on-site at refueling station or off-site in central plants (Klell et al., 2018). By using the latter, transport is needed which will be further discussed in green MAGIC step 4.

\subsection{Step 2: Energy Production}

As just mentioned, water electrolysis represents the only opportunity for generating commercial 'green' hydrogen. At this juncture the source of electricity is fundamental, which determines the $\mathrm{CO} 2$ content. Based on green MAGIC we consider two options of energy supply, comprising 1) constant electricity from grid mix and 2) electricity from fluctuating renewable energy sources, e.g. wind, solar and hydropower energy. In case of electrolysis using grid mix electricity, $\mathrm{CO} 2$ emissions depend on the share of renewable energies within the mix. Even if renewable shares increase annually (EUROSTAT, 2020), large emissions remain which categorizes grid $\mathrm{H} 2$ as 'grey'. Considering water electrolysis using exclusively renewable excess energy, the procedure as well as the generated 'green' $\mathrm{H} 2$ are evaluated by zero-emission, which is evaluated as the current only option to produce carbon-free $\mathrm{H} 2$ in usable quantities (Töpler and Lehmann, 2017). Apart from the elementary difference in terms of CO2 emissions, 'green' $\mathrm{H} 2$ is about $1,5-4 € / \mathrm{kg}$ more expensive than 'grey' H2 (EMCEL, 2019). This relatively poor economic performance is seen as a large challenge and will affect the Hydrogen-bus project as well (Klell et al., 2018).

\subsection{Step 3: Conversion}

As green MACIC step 1 defined the source of H2 (e.g. electrolysis) and step 2 the energy origin (e.g. renewable electricity), step 3 deals with the conversion. Choosing the pathway 'water electrolysis with renewable excess energy' to generate green $\mathrm{H} 2$, these conversion processes are often summarized as Power-to-Gas (PtG), Power-to-Hydrogen or according to the type of renewable electricity supply, e.g. as Wind-to-Hydrogen (w2h). Within the electrolysis, there are numerous types which differ mainly between the electrolyte used. Noteworthy processes are alkaline (AEL), polymer electrolyte membrane (PEMEL) and high-temperature electrolysis (HTEL). It should be noted that AEL is already for a long time in commercial use and represents the most common form worldwide. In addition, PEMEL is regarded as a hope which offers cost saving potentials due to its simple construction and its higher achievable current densities. As none of them emit emissions, efficiency can be the parameter for evaluation whereof all three mentioned variants can achieve $80 \%$ efficiency and more (Klell et al., 2018). With respect to Hydrogen-bus project and a commercial H2 supply, Figure 4 summarizes key statements of just discussed green MAGIC steps 1 to 3. Beside observing highest $\mathrm{CO} 2$-emissions of grey $\mathrm{H} 2$, an important point to recognize is that only electrolysis (AEL) and steam reforming are usually on-site feasible (Reuter et al., 2017). The lowest H2-price can be expected from SMR while water electrolysis based on renewable energy delivers the best ecological performance by far (Töpler and Lehmann, 2017).

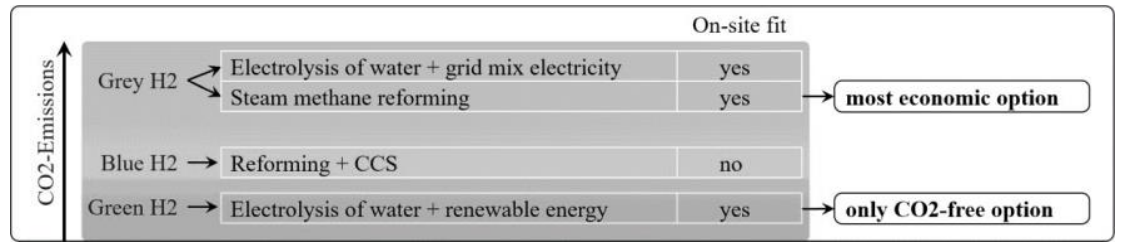

Figure 4. Options for commercial H2 supply; based on (IRENA, 2019); (Klell et al., 2018) 


\subsection{Step 4: H2 Storage \& Distribution}

Within green MAGIC step 4 - concerning H2 storage \& distribution - the chemical properties of $\mathrm{H} 2$ are a decisive factor, so there is need to mention important ones. In comparison to other fuels (e.g. gasoline), $\mathrm{H} 2$ has a higher mass-specific (W/kg), but at the same time a significant smaller volume specific energy density (W/1). Its boiling point is $-253{ }^{\circ} \mathrm{C}$ and above, considering ambient conditions, $\mathrm{H} 2$ is gaseous. Therefore, one is anxious to increase volumetric energy density to achieve storage \& distribution benefits by either compressing or liquefying the gas, as summarized in Table 1 (Klell et al., 2018).

Table 1. Density and energy content of hydrogen (Klell et al., 2018)

\begin{tabular}{|l|l|l|l|}
\hline Conditions & Density [in $\mathbf{1 m}^{3}$ ] & Energy content [in $\mathbf{1 m}^{3}$ ] & Energy required \\
\hline $\mathrm{H} 2: 1 \mathrm{bar}, 25^{\circ} \mathrm{C}$ & $0,081 \mathrm{~kg} \mathrm{H}_{2}$ & $10,7 \mathrm{MJ}(2,7 \mathrm{kWh})$ & - \\
\hline $\mathrm{CGH} 2: 350 \mathrm{bar}, 25^{\circ} \mathrm{C}$ & $23,3 \mathrm{~kg} \mathrm{H}_{2}$ & $2.630 \mathrm{MJ}(731 \mathrm{kWh})$ & $\sim 15 \%$ \\
\hline $\mathrm{LH} 2: 1 \mathrm{bar},-253^{\circ} \mathrm{C}$ & $70,8 \mathrm{~kg} \mathrm{H}_{2}$ & $8.495 \mathrm{MJ}(2361 \mathrm{kWh})$ & $\sim 20-30 \%$ \\
\hline
\end{tabular}

From $\mathrm{H} 2$ generation to intermediate storage and distribution to the end user, several gas pressure levels between 50 bar up to 1.000 bar are used (Adolf et al., 2017). Storage \& distribution in a suitable way is thus complex for which reason we discuss the most important options, starting with storage followed by the distribution part afterwards. The first options are subsurface storage in salt cavern and pore storage based on artificially created cavities in the underground, allowing to store H2 large scale in the long-term (Wencker and Kukuk, 2020). The second option representing the most common one is particularly focused on gaseous compressed hydrogen (CGH2) in pressure tanks with 350 or 700 bar, which can be used for both stationary as well as mobile storage. In terms of vehicle range, pressure levels play a decisive role. The higher the pressure, the more $\mathrm{H} 2$ is available in the vehicle tank with the same volume. For $\mathrm{H} 2$ bus on-board storage, 350 bar is the currently established pressure level (Huss and Corneille, 2012). The third and almost sophisticated storage option at present are cryogenic liquid hydrogen (LH2) storage in vacuum-insulated containers, storing LH2 below its boiling point of $-253{ }^{\circ} \mathrm{C}$ (Wencker and Kukuk, 2020). LH2 storage is also used on-board and stationary, with significantly fewer applications compared to $\mathrm{CGH} 2$. Both compression and especially liquefying processes result in a storage benefit on one side, with efficiency losses on the other. The energy required is about $15 \%$ for compressing and $20-30 \%$ for liquefying of $\mathrm{H} 2$ heating value (see Table 1). Summed up, LH2 brings a significant higher energy density compared to $\mathrm{CGH} 2$, but also requires a higher amount of energy. For H2 buses, a continuous field of tension between maximum range and simultaneously minimum weight, tank volume and costs exist (Klell et al., 2018). Since conversion leads to losses, alternative storage methods are a highly relevant field of research that is actively promoted at this time. To be mentioned are methods like Liquid Organic Hydrogen Carriers (LOHCs) as well as kinds of hybrid storage which do not play a further role due to their low stage of development (Adolf et al., 2017).

After $\mathrm{H} 2$ storage, the following part concerns $\mathrm{H} 2$ distribution. As mentioned in step 1, in case of onsite production, we don't need to consider transport anymore. Otherwise when assuming off-site production in central plants, transport is required which causes additional $\mathrm{WtW}$ energy losses and $\mathrm{CO} 2$ emissions. Advantages in favor of centralized production on the other hand are for instance a general higher plant efficiency and a much wider choice of methods compared to on-site ones (Reuter et al., 2017). H2 is transported either by truck (CGH2 or LH2) or in pipelines (CGH2). The alternative used depends basically on the parameters $\mathrm{H} 2$ amount and transport distance. Pipelines are not suitable for urban $\mathrm{H} 2$ supply and thus no longer considered. While comparing CGH2 with LH2 delivery, the latter can transport about three to four times more of $\mathrm{H} 2$ due to increased densities (see Table 1). On the other side, the significant higher amount of energy required for liquefaction leads to higher production costs. Even if $\mathrm{CGH} 2$ truck delivery is basically the more economical option up to a certain distance and LH2 delivery beyond this threshold, its primary aim is to choose the best transport option for each individual purpose. Same goes for Hydrogen-bus project. Even if $\mathrm{H} 2$ supply is currently largely based on CGH2 truck delivery, there is no general solution. Based on mentioned parameters $\mathrm{H} 2$ amount and delivery distance, the most optimal solution must always be weighed for each individual case. Both $\mathrm{H} 2$ distribution as well as storage is a challenge, whereas the advantages must always be carefully put in relation to the disadvantages, in order to reach the best option (Reuter et al., 2017). 


\section{MAIN FINDINGS AND BENEFIT}

For a complete understanding of environmental impacts and energy balances associated with hydrogen fueled buses during its entire life cycle, a holistic approach from Well to Wheel is greatly required. For our case, we chose green MAGIC approach serving as an overall framework to allow the desired holistic view. Within green MACIC we conclude that Well-to-Tank refers to step 1 to 4 while Tank-to-Wheel is represented by step $5+6$. In this paper we investigated step 1 to 4 with respect to green $\mathrm{H} 2$ supply for a H2-city-bus. We conclude that there are numerous options which can be combined in various ways and the choice of options contains a continuous field of tension between profitability, efficiency and ecology, whereas in most cases the most economic alternative dominates. Water electrolysis using exclusively renewable excess energy is evaluated as the currently only option to produce 'green' $\mathrm{H} 2$ in usable quantity, whereby its not yet economical competitive to 'grey' $\mathrm{H} 2$ from conventional procedures. Summed up, even though each step from Well-to-Tank has a state-of-the-art option, there is no general solution. The most suitable WtT-path must always be weighed for each individual case by defining individual defined premises. Step 5 Fueling \& Application and step 6 Further Usage representing Tankto-Wheel perspective will be the object of investigation within Hydrogen-bus project, where we intent to involve real data in a H2-ICE bus. Within this literature review the focus was set on H2-ICE buses in the foreground with an extended view to HDVs on one hand and to the FC-technology on the other, representing the H2-based counterpart. Regarding H2-ICE buses and HDVs, studies are rare and applications in daily operation are non-existent. The last and noteworthy H2-ICE bus application in real driving operation can be found in Berlin between 2006 and 2014 within demonstration project CHIC (Fuel Cells and Hydrogen Joint Undertaking, 2018). With respect to HDVs based on FC, we identify the Hyundai Xcient FC as the first and currently only vehicle in daily operation and research is carried out in parallel. With a view to FC-based buses the development is already much more advanced representing by several past as well as ongoing projects. For example, the most recently announced 'H2Bus' consortium aiming to deploy 600 FC electric buses within the EU due by 2023 and 1.000 vehicles in total. In addition, the literature review has shown, that WtW investigations of $\mathrm{H} 2$-based buses and HDVs as well as benchmarks with other AFP have already been performed in many ways, which are also almost entirely focused on FC technology. In context of Hydrogen-bus project, one can profit from existing FC applications and studies in so far, since the WtTview - represented by green MAGIC step 1 to 4 - can be transferred equally to $\mathrm{H} 2$-ICE vehicles. A further advantage is to generate synergy effects from FC application, e.g. more commitment by affectedstakeholders to support market deployment. There is also agreement that without further political measures the development of $\mathrm{H} 2$ economy will be hampered and emissions will continue to rise.

The general focus on FC technology is comprehensible, since they have some important advantages compared to H2-ICEs, particularly a significant higher efficiency and thus lower hydrogen consumptions. However, some substantial arguments in favor of the H2-ICE technology exist as well, including a $\mathrm{CO} 2$-free combustion procedure, the use of existing manufacturing structures and a high tolerance to $\mathrm{H} 2$ purities. In particular, the use of existing manufacturing facilities and processes from conventional ICE, which has been optimized over the past century, allows mass-production. This results in reduced costs whereby exactly costs are currently seen as the key barrier to market penetration of FCtechnology. Summarized by the main characteristics of H2-ICEs, closely connected to the basic properties of $\mathrm{H} 2$, motivation of further research is well-founded.

\section{CONCLUSION}

This paper intends to take a deeper look into the hydrogen combustion engine technology (H2-ICE) for buses and HDVs and reveals the state of H2-ICE development based on current literature. It was shown that due to the present domination of diesel vehicles in road transport sector a transformation is greatly required, whereas hydrogen fuel represents a promising option due to its carbon-free content. Beside the H2-ICE technology in the foreground we extended our view to fuel cells as its hydrogen-based counterpart. Based on a significant larger number of published studies as well as observed application we conclude, that fuel cells are seen as the obvious preferable $\mathrm{H} 2$ technology for mobile purposes. Nevertheless, the H2-ICE technology provides also some advantages justifying further research. Potential is seen by a small amount of manufacturer who are testing H2-ICE applications most recently within a few isolated pilot tests. It is worth mentioning that companies working on the H2-ICE technology include both a Start-Up as well as a large OEM of commercial vehicle sector. 
In general, the fundamental necessity of carbon-free propulsion systems is out of question. Within hydrogen fueled buses and HDVs, applications are doubtless largely based on fuel cells. Research on $\mathrm{H} 2-\mathrm{ICE}$ technology is but likewise currently reigniting and gains relevance. Since H2-ICE vehicles are fed by 'green' hydrogen, they represent a holistic Well-to-Wheel carbon-free propulsion system, helping to decarbonize road transport sector and to achieve climate targets as the overall goal. Therefore, it is to be expected that H2-ICE vehicles will be increasingly tested. Whether the H2-ICE technology accelerates only the development of hydrogen mobility and serves as a preliminary bridging technology, whether it will soon disappear from the market or even establish itself in the long-term will be shown in the near future in tests by e.g. MAN as well as in the upcoming Hydrogen-bus project, where tests on $\mathrm{H} 2$-ICE based buses in real operation are foreseen.

\section{REFERENCES}

Adolf, J., Balzer, C.H., Louis, J., Schabla, U., Fischedick, M., Arnold, M., Pastowski, A. and Schüwer, D. (2017), Shell Wasserstoff-Studie: Energie der Zukunft?, Shell Deutschland Oil GmbH, Hamburg.

Ambel, C.C. (2017), Roadmap to climate-friendly land freight and buses in Europe, Transport \& Environment, Brussels.

Delago, O. and Muncrief, R. (2016), "New Study on Technology Potential for EU Tractor-Trailers", Road to Efficiency Workshop, Brussels, June 09, 2016, ICCT, Brussels.

Eichlseder, H., Grabner, P. and Schaffer, K. (2020), "Internal Combustion Engine - An Alternative Energy Converter for Hydrogen", TU Graz research No. 23, pp. 27-30.

El Hannach, M., Ahmadi, P., Guzman, L., Pickup, S. and Kjeang, E. (2019), "Life cycle assessment of hydrogen and diesel dual-fuel class 8 heavy duty trucks", International Journal of Hydrogen Energy, Vol. 44 No. 16, pp. 8575-8584. https://dx.doi.org/10.1016/j.jhhydene.2019.02.027.

Eliasson, C. and Martens, F. (2020), Joint Venture between the Volvo Group and Daimler Truck AG[online], Volvo Group, available at: https://www.volvogroup.com/en-en/news/2020/apr/news- 3640568.html (accessed 23 November 2020).

EMCEL (2019), Was kostet grüner Wasserstoff? [online], EMCEL, available at: https://emcel.com/de/waskostet-gruener-h2/ (accessed 23 November 2020).

European Union (2009), "Directive 2009/33/EC of the European Parliament and of the Council of 23 April 2009 on the promotion of clean and energy-efficient road transport vehicles Text with EEA relevance", Official Journal of the European Union No. L 120, pp. 5-12.

European Union (2014), WELL-TO-WHEELS Report version 4.a. https://dx.doi.org/10.2790/95533.

EUROSTAT (2020), Share of renewable energy in the EU up to $18.0 \%$ [online], available at: https://ec.europa.eu/eurostat/documents/2995521/10335438/8-23012020-AP-EN.pdf/292cf2e5- 8870-45257 ad7-188864ba0c29 (accessed 23 November 2020).

FAU (2020), Gemeinsamer Wasserstoff-Campus [online], FAU, available at: https://www.fau.de/ 2020/10/news/panorama/gemeinsamer-wasserstoff-campus/ (accessed 23 November 2020).

Fuel Cells and Hydrogen Joint Undertaking (2018), Strategies for joint procurement of fuel cell buses. https://dx.doi.org/10.2843/459429.

Gnann, T., Plötz, P., Wietschel, M. and Kühn, A. (2017), "What is the best alternative drive train for heavy road transport?", EVS30 Symposium, Stuttgart, October 9 - 11, 2017, Fraunhofer ISI, Stuttgart.

Guandalini, G. and Campanari, S. (2018), "Well-to-wheel driving cycle simulations for freight transportation: battery and hydrogen fuel cell electric vehicles", pp. 1-6. https://dx.doi.org/10.23919/EETA.2018.8493216.

Gupta, P., Tong, D., Wang, J., Zhuge, W., Yan, C., Wu, Y., Luo, S., He, X. and Ma, F. (2020), "Well-to-wheels total energy and GHG emissions of HCNG heavy-duty vehicles in China: Case of EEV qualified EURO 5 emissions scenario", International Journal of Hydrogen Energy, Vol. 45 No. 15, pp. 8002-8014. https://dx.doi.org/10.1016/j.ijhydene.2020.01.025.

H2Bus (2020), Presenting the H2Bus Consortium [online], H2Bus, available at: https://h2bus.eu/(accessed 23 November 2020).

H2Haul (2020), About the H2Haul project [online], H2Haul, available at: https://www.h2haul.eu/about/ (accessed 23 November 2020).

Huss, A. and Corneille, M. (2012), Wasserstoff-Tankstellen, Hessisches Ministerium für Umwelt, Energie, Landwirtschaft und Verbraucherschutz, Wiesbaden.

Hydrogen Europe (2020), Project JIVE 2 [online], Hydrogen Europe, available at: https://hydrogeneurope.eu/project/jive-2 (accessed 23 November 2020).

Hyundai (2020), Hyundai Xcient FC [online], Hyundai Hydrogen Mobility, available at: https://hyundaihm.com/en/unser-truck/ (accessed 23 November 2020).

IEA (2019), Global Energy \& CO2 Status Report 2018, IEA, France by IEA.

IRENA (2019), Hydrogen: A renewable energy perspective, IRENA, Abu Dhabi. 
Klell, M., Eichlseder, H. and Trattner, A. (2018), Wasserstoff in der Fahrzeugtechnik, Springer,Wiesbaden. https://dx.doi.org/10.1007/978-3-658-20447-1.

Klepatz, K., Zeilinga, S., Rottengruber, H., Koch, D., Prümm, F.W. and Sousa, A. (2019), "Verlustanalyse eines direkteinblasenden Wasserstoffverbrennungsmotors”, in Tschöke, H. and Marohn, R. (Eds.), 11. Tagung Einspritzung und Kraftstoffe 2018, Proceedings, Springer, Wiesbaden, pp. 395-422. https://dx.doi.org/10.1007/978-3-658-23181-1_20.

Kluschke, P., Gnann, T., Plötz, P. and Wietschel, M. (2019), "Market diffusion of alternative fuels and powertrains in heavy-duty vehicles: A literature review”, Energy Reports, Vol. 5, pp. 1010-1024. https://dx.doi.org/10.1016/j.egyr.2019.07.017.

Koch, D., Ebert, T. and Sousa, A. (2020), "Engine Adaptation from Diesel to H2 HP-EGR Lean Combustion Concept”, MTZ worldwide, Vol. 81 No. 5, pp. 30-37. https://dx.doi.org/10.1007/s38313-020-0223-9.

Korn, T. and Volpert, G. (2019), "The hybrid model of the new hydrogen combustion engine as the most efficient powertrain of tomorrow", in Liebl, J. (Ed.), Der Antrieb von morgen 2019, Proceedings, Springer, Wiesbaden, pp. 87-101. https://dx.doi.org/10.1007/978-3-658-26056-9_6.

Lozanovski, A., Whitehouse, N., Ko, N. and Whitehouse, S. (2018), "Sustainability Assessment ofFuel Cell Buses in Public Transport", Sustainability, Vol. 10 No. 5, p. 1480. https://dx.doi.org/10.3390/su10051480.

OECD/IEA (2017), The Future of Trucks, IEA, France by IEA.

Pachauri, R.K. and Mayer, L. (2015), Climate change 2014, Intergovernmental Panel on Climate Change, Geneva, Switzerland.

Reich, G. and Reppich, M. (2018), Regenerative Energietechnik, Springer, Wiesbaden. https://dx.doi.org/10.1007/978-3-658-20608-6.

Reuter, B., Faltenbacher, M., Schuller, O., Whitehouse, N. and Whitehouse, S. (2017), New Bus ReFuelling for European Hydrogen Bus Depots, Fuel Cells and Hydrogen Joint Undertaking,Leinfelden-Echterdingen.

Salehi, D.V. (2020), green MAGIC approach, Munich University of Applied Sciences, Munich.

Salehi, V. and Wang, S. (2019), "Munich Agile MBSE Concept (MAGIC)", in Proceedings of the 22nd ICED 2019, The Netherlands, November 5 - 8, 2019, Munich University of Applied Sciences, The Netherlands. https://dx.doi.org/10.1017/dsi.2019.377.

Töpler, J. and Lehmann, J. (2017), Wasserstoff und Brennstoffzelle, Springer, Berlin, Heidelberg. https://dx.doi.org/10.1007/978-3-662-53360-4.

United Nations (2015), "2015 Paris Aggreement UNFCCC", Conference of the Parties, Twenty-firstsession, Paris, November 30 - December 11, 2015, FCCC, Paris.

VW AG (2020), MAN presents Zero-Emission Roadmap [online], VW AG, available at: https://www.volkswagenag.com/en/news/2020/10/MAN-presents-Zero-Emission-Roadmap.html (accessed 23 November 2020).

Wencker, T. and Kukuk, J. (2020), Energieträger Wasserstoff, ASUE: Arbeitsgemeinschaft fürsparsamen und umweltfreundlichen Energieverbrauch e.V., Berlin.

Wietschel, M., Gnann, T., Thielmann, A. and Kühn, A. (2016), "Stand der Forschung, Marktpotenziale und Forschungsbedarf für Brennstoffzellen-LKW”, MKS-Fachworkshop, Berlin,June 30, 2016, Fraunhofer ISI, Berlin.

Yip, H.L., Srna, A., Yuen, A.C.Y., Kook, S., Taylor, R.A., Yeoh, G.H., Medwell, P.R. and Chan, Q.N. (2019), "A Review of Hydrogen Direct Injection for Internal Combustion Engines: Towards Carbon-Free Combustion", Applied Sciences, Vol. 9 No. 22, p. 4842. https://dx.doi.org/10.3390/app9224842. 